\title{
THE EFFECT OF THERMAL TREATMENT ON PHYSICAL AND MECHANICAL PROPERTIES OF Luehea divaricata HARDWOOD
}

\author{
Eduardo Schneid ${ }^{1}$, Pedro Henrique Gonzalez de Cademartori ${ }^{2, \diamond}$, Darci Gatto ${ }^{3}$
}

\begin{abstract}
This study aimed to characterise the effect of thermal treatment on physical and mechanical properties of açoita-cavalo (Luehea divaricata) wood. To achieve this, samples were treated at 160,180 and $200^{\circ} \mathrm{C}$ for 2 $\mathrm{h}$ in an oven (dry conditions). Physical and mechanical characterisation was performed by weight loss, dry specific gravity at $12 \%$, equilibrium moisture content, volumetric swelling and shrinkage, water absorption, water repellence, static bending and brittleness tests. Roughness and colour tests were performed in order to evaluate the modified surface. Main findings showed that dimensional stability of thermally modified wood increased, while mechanical strength of wood decreased as a function of temperature. A darkening of wood and a decrease in roughness were observed.
\end{abstract}

Keywords: Brittleness, dimesional stability, modulus of elasticyty, modulus of rupture, roughness.

\section{INTRODUCTION}

Currently, wood from native species in Brazil does not have the same importance as raw material for timber products due to the increase of fast-growing forests over the last years. Even so, wood presents limitations when in service because it is highly hygroscopic and anisotropic.

Açoita-cavalo (Luehea divaricata) is present in Brazil from the states of Minas Gerais and Rio de Janeiro to Rio Grande do Sul, as well as in other countries: Argentina, Uruguay and Paraguay. Açoita-cavalo wood has many uses, such as for furniture production, slats, moulding and skirting. However, wood from açoitacavalo cannot be exposed to environments with a high level of biological degradation because it has low natural durability (Rizzini 1995).

Thermal modification was developed as an alternative to traditional wood treatments such as impregnation with chemical products (toxic products) that aims to improve wood properties. Thermal treatment is a process of modification of different materials at high temperatures, which can be performed between 180 and $260^{\circ} \mathrm{C}$ (Hill 2006). Nevertheless, thermal treatments also could be performed in lower temperatures $\left(140\right.$ and $160^{\circ} \mathrm{C}$, for example) as observed in previous studies (Pincelli 2012, Bal 2013).

Thermal treatment causes changes on wood, mainly related to their physical and mechanical properties. Amongst physical properties, emphasis is on weight loss, increase of dimensional stability and colour changes. Sundqvist et al. (2006) reported that weight loss of white birch wood treated at $160-200^{\circ} \mathrm{C}$ for $1-4$ hours was directly related to the temperature of treatment. Colour changes on wood occur due to the modification of hemicelluloses structure, migration of extractives to surface and formation of oxidative products. Changes in chemical compounds induce darkening of thermally modified wood (Bekhta and Niemz 2003, Esteves et al. 2008, Akyildiz et al. 2009).

\footnotetext{
' College of Civil Engineering, Departament of Civil Engineering, Federal University of Santa Catarina, Florianópolis, SC, Brazil. eduardoschneid87@gmail.com Wood and Forestry Science Centre (PPGEF), Federal University of Paraná, Curitiba, PR, Brazil. pedrocademartori@gmail.com

${ }^{3}$ College of Materials Engineering (PPGCEM), Development Centre of Technology (CDTec), Federal University of Pelotas, Pelotas, RS, Brazil. darcig atto@yahoo.com

^Corresponding author: pedrocademartori@gmail.com

Received: 20.02.2013 Accepted: 18.12. 2013
} 
However, mechanical properties are often negatively affected by thermal treatments. Bekhta and Niemz (2003) observed a decrease between 4 and $9 \%$ of modulus of elasticity at static bending in Norway spruce wood thermally modified at $200^{\circ} \mathrm{C}$ for 2 and 24 hours. Likewise, Militz and Tjeerdsma (2001) affirmed that flexural strength of Fagus sylvatica (European beech), Betula pendula (silver birch), Pseudotsuga menziesii (Douglas-fir), Pinus sylvestris (Scots pine) and Pinus radiata (Radiata pine) decreased between 5 and 18\% when treated by "Plato-Process ${ }^{\mathbb{}}$ ".

Considering aforementioned characteristics of thermal treatments and wood from Luehea divaricata specie, thermal modification could be a great alternative to improve their physical properties and to increase their aesthetic uses, since that açoita-cavalo wood is widely used for furniture production and other non-structural products, mainly in South American market.

In this context, this study aimed to evaluate physical and mechanical properties of açoita-cavalo (Luehea divaricata) thermally modified wood. Physical properties were characterised using several tests related to weight loss, dimensional stability, surface roughness and colour changes, while mechanical properties were evaluated using static bending tests to characterise stiffness, strength and brittleness of wood.

\section{MATERIAL AND METHODS}

Ten açoita-cavalo (Luehea divaricata Mart. et Zucc Mart.) trees were randomly selected and harvested (licensing process by the State Ministry of Environment) from two regions located in Southern Brazil (29 ${ }^{\circ} 14^{\prime} 30.91^{\prime}$ 'S, $52^{\circ} 18^{\prime} 47.65^{\prime}$ 'O), namely Central Depression and Upper Northeast Slopes.

The first log measuring $2500 \mathrm{~mm}$ length of each tree was cut in order to obtain $80 \mathrm{~mm}$ thick boards. Fifty-two samples measuring $25 \times 25 \times 410 \mathrm{~mm}$ (radial x tangential x longitudinal) were prepared, all of them flawless and with straight grain orientations.

Thermal treatments were performed in an electric oven without forced air circulation and heating rate of $2^{\circ} \mathrm{C} / \mathrm{min}$. Samples were treated at 160,180 and $200^{\circ} \mathrm{C}$ for $2 \mathrm{~h}$. After the thermal treatments, the samples were put in a desiccator until to reach room temperature. Control samples (untreated) were kept in a climate chamber at $25^{\circ} \mathrm{C}$ and $65 \%$ of relative humidity until to perform the physical and mechanical tests.

\section{Physical properties}

Weight loss was measured by the difference of dry weight before and after thermal treatments (Equation 1). Dry specific gravity at $12 \%$ of moisture content was measured by equation 2 .

$$
\begin{gathered}
\mathrm{WL}=\frac{\mathrm{M}_{\mathrm{BH}}-\mathrm{M}_{\mathrm{AH}}}{\mathrm{M}_{\mathrm{BH}}} \times 100 \\
\rho_{12 \%}=\frac{\mathrm{M}_{0}}{\mathrm{~V}_{12 \%}} \times 100
\end{gathered}
$$

$\mathrm{WL}=$ weight loss (\%); $\mathrm{M}_{\mathrm{BH}}=$ dry weight of samples before thermal treatment (g); $\mathrm{M}_{\mathrm{AH}}=$ dry weight of samples after thermal treatment $(\mathrm{g}) ; \rho_{12 \%}=$ dry specific gravity at $12 \%\left(\mathrm{~g} / \mathrm{cm}^{3}\right) ; \mathrm{M}_{0}=$ dry weight of samples $(\mathrm{g}) ; \mathrm{V}_{12 \%}=$ volume at $12 \%$ of samples $\left(\mathrm{cm}^{3}\right)$. 
Samples measuring $25 \times 25 \times 50 \mathrm{~mm}$ (radial x tangential x longitudinal) were cut from original samples in order to evaluate dimensional stability after fully saturation. Volumetric swelling, volumetric shrinkage, water absorption and water repellence were measured by equations $3,4,5$ and 6 .

$$
\begin{gathered}
\alpha_{\mathrm{v}}=\left(\frac{\mathrm{Vu}-\mathrm{Vo}}{\mathrm{Vo}}\right) \times 100 \\
\mathrm{~B}_{\mathrm{v}}=\left(\frac{\mathrm{Vu}-\mathrm{Vo}}{\mathrm{Vu}}\right) \times 100 \\
\mathrm{WA}=\left(\frac{\mathrm{Mu}-\mathrm{Ms}}{\mathrm{Ms}}\right) \times 100 \\
\mathrm{WRE}=\left(\frac{\mathrm{TR}_{\mathrm{H} 2 \mathrm{O}}-\mathrm{TT}_{\mathrm{H} 2 \mathrm{O}}}{\mathrm{TR}_{\mathrm{H} 2 \mathrm{O}}}\right) \times 100
\end{gathered}
$$

$\alpha v=$ volumetric swelling $(\%) ; \beta v=$ volumetric shrinkage $(\%) ; \mathrm{Vu}=$ saturated volume of samples $\left(\mathrm{cm}^{3}\right)$; $\mathrm{Vo}=$ volume of dried samples $\left(\mathrm{cm}^{3}\right) ; \mathrm{WA}=$ water absorption $(\%) ; \mathrm{Mu}=$ saturated weight of samples; $\mathrm{Ms}=$ dry weight of samples; $\mathrm{WRE}=$ water repellence $(\%) ; \mathrm{TR}_{\mathrm{H} 2 \mathrm{O}}=$ mean water absorption of untreated samples $(\%)$ $\mathrm{TT}_{\mathrm{H} 2 \mathrm{O}}=$ mean water absorption of treated samples (\%).

\section{Mechanical properties}

Mechanical tests were performed in an universal machine (EMIC) with capacity of $300 \mathrm{kN}$. Static bending tests were performed in a three-point bending apparatus with a span length of $360 \mathrm{~mm}$ and a loading speed of $1,30 \mathrm{~mm} / \mathrm{min}$, according to the American Society for Testing and Materials - ASTM D 143-94 (ASTM 2000).

After the mechanical tests, the load-deflection curves were analysed in order to estimate the brittleness of untreated and thermally treated wood according to the methodology described by Phuong et al. (2007).

\section{Colorimetric evaluation}

Changes on colour of thermally modified wood were performed by a colorimeter (Konica Minolta CR400). The equipment was configured to use a D65 illuminant and $10^{\circ}$ standard observer (CIE-Lab standard).

Two measurements for each sample in both radial and tangential section were performed in order to obtain the parameters $L^{*}$ (lightness), $a^{*}$ (red-green chromatic coordinate and $b^{*}$ (yellow-blue chromatic coordinate).

$\Delta E$ (colour difference), $C^{*}$ (saturation) and $h$ (hue angle) were measured by equations 7,8 and 9.

$$
\begin{gathered}
\Delta \mathrm{E}=\left(\Delta \mathrm{L}^{* 2}+\Delta \mathrm{a}^{* 2}+\Delta \mathrm{b}^{* 2}\right)^{1 / 2} \\
\mathrm{C}^{*}=\left(\mathrm{a}^{* 2}+\mathrm{b}^{* 2}\right)^{1 / 2} \\
\mathrm{~h}=\operatorname{tang}^{-1}\left(\mathrm{~b}^{*} / \mathrm{a}^{*}\right)
\end{gathered}
$$

$\Delta \mathrm{E}=$ colour difference; $\Delta \mathrm{L}^{* 2}, \Delta \mathrm{a}^{* 2}$ and $\Delta \mathrm{b}^{* 2}=$ variation of lightness, red-green chromatic coordinate and blue-yellow chromatic coordinate between untreated and treated samples; $C^{*}=$ saturation; $h=$ hue angle; $a^{*}=$ red-green chromatic coordinate; $b^{*}=$ yellow-blue chromatic coordinate. 


\section{Surface roughness evaluation}

Surface roughness was carried out by a profilometer based on stylus device standard (Homis model 899), which can detects variations on height of wood surface using a probe in a predetermined distance. The profilometer was configured with a cut-off length of $2,5 \mathrm{~mm}$, tracing line of $5 \mathrm{~mm}$, pin diameter of $5 \mathrm{~mm}$ and pin top angle of $90^{\circ}$.

Measurements were performed in three distinct points of surface samples (perpendicular to the fibres) in radial section of each treatment in order to obtain four parameters, $\mathrm{Ra}$ (mean arithmetic deviation of profile), $\mathrm{Rz}$ (mean peak to-valley height), $\mathrm{Rq}$ (root mean square roughness) and $\mathrm{Rt}$ (maximum roughness).

\section{Statistical analysis}

The collected data was analysed using descriptive statistic and analysis of variance $(\mathrm{p}<0.05)$. When the null hypothesis was rejected, the average values were compared with Tukey Test at $5 \%$ level of probability of error.

\section{RESULTS AND DISCUSSION}

Mean values of $\rho_{12 \%}$ did not show statistical difference (Table 1), however a slight reduction as a function of treatment temperature was observed. On the other hand, EMC significant varied in relation to the control treatment (untreated samples). Mean values of EMC (Table 1) vary between 6 and 7\%, in which the highest reduction was found in the treatment at $200^{\circ} \mathrm{C}(\sim 35 \%)$. Günduz and Aydemir (2009) also found decrease of EMC in Carpinus betulus wood after thermal treatment at $170-210^{\circ} \mathrm{C}$ for $4-12 \mathrm{~h}$.

Table 1. Mean values of dry specific gravity at $12 \%\left(\rho_{12 \%}\right)$, equilibrium moisture content (EMC) and weight loss (WL) of Luehea divaricata (açoita-cavalo) untreated and thermally treated.

\begin{tabular}{cccc}
\hline Treatment $\left({ }^{\circ} \mathrm{C}\right)$ & $\rho_{12 \%}\left(\mathrm{~g} / \mathrm{cm}^{3}\right)$ & EMC 65\% $(\%)$ & WL $(\%)$ \\
\hline Control $(20)$ & $0,61(0,03) \mathrm{a}$ & $10,28(0,55) \mathrm{a}$ & - \\
160 & $0,59(0,03) \mathrm{a}$ & $7,45(1,53) \mathrm{b}$ & $1,09 \mathrm{a}(17,36)$ \\
180 & $0,59(0,04) \mathrm{a}$ & $7,19(0,72) \mathrm{b}$ & $1,81 \mathrm{a}(11,70)$ \\
200 & $0,57(0,04) \mathrm{a}$ & $6,63(0,46) \mathrm{b}$ & $5,49 \mathrm{~b}(28,08)$ \\
\hline \multirow{2}{*}{ ANOVA } & $\mathrm{F}=1,85$ & $\mathrm{~F}=41,12^{* *}$ & $\mathrm{~F}=60,81 * *$ \\
& $\mathrm{p}=0,1513$ & $\mathrm{p}<0,01$ & $\mathrm{p}<0,01$ \\
\hline
\end{tabular}

Mean values in the same column followed by the same letter are not statistically different at level of $5 \%$ by the Tukey Test; $\mathrm{p}=$ probability; $\mathrm{F}=$ calculated value of $\mathrm{F} ; * *$ Significant at $5 \%$ of probability of error; Value between parenthesis corresponding to coefficient of variation (\%).

WL was directly proportional to the temperature of treatment (Table 1). However, significant weight loss was observed only at $200^{\circ} \mathrm{C}$. According to Sundqvist et al. (2006), hemicelluloses presents great changes in its chemical structure when treated at $180-200^{\circ} \mathrm{C}$ for 2,5 and $4 \mathrm{~h}$, which generating significant weight loss of wood.

The increase of dimensional stability of wood is one of the most important changes due to thermal treatments. The behaviour of the parameters related to the dimensional stability of untreated and thermally treated samples is verified in table 2 . 
Table 2. Mean values of volumetric swelling ( $\alpha \mathrm{v})$, volumetric shrinkage ( $\beta \mathrm{v})$, water absorption (WA) and water repellence (WRE) of Luehea divaricata (açoita-cavalo) untreated and thermally treated.

\begin{tabular}{ccccc}
\hline Treatment $\left({ }^{\circ} \mathrm{C}\right)$ & $\alpha \mathrm{v}(\%)$ & $\beta \mathrm{v}(\%)$ & WA $(\%)$ & WRE $(\%)$ \\
\hline Control $(20)$ & $12,55 \mathrm{a}(0,99)$ & $11,45 \mathrm{a}(1,63)$ & $137,28 \mathrm{a}(11,18)$ & - \\
160 & $12,11 \mathrm{a}(1,56)$ & $10,61 \mathrm{a}(1,25)$ & $134,91 \mathrm{a}(12,49)$ & 1,72 \\
180 & $11,59 \mathrm{a}(1,05)$ & $10,46 \mathrm{a}(0,82)$ & $136,36 \mathrm{a}(6,18)$ & 0,67 \\
200 & $10,12 \mathrm{~b}(1,10)$ & $9,15 \mathrm{~b}(0,91)$ & $129,49 \mathrm{a}(8,66)$ & 5,67 \\
\hline \multirow{2}{*}{ ANOVA } & $\mathrm{F}=7,78^{* *}$ & $\mathrm{~F}=6,96^{* *}$ & $\mathrm{~F}=0,31$ & - \\
& $\mathrm{p}<0,0001$ & $\mathrm{p}<0,0001$ & $\mathrm{p}=0,82$ & - \\
\hline
\end{tabular}

Statistical prerequisites as in Table 1 .

$\alpha \mathrm{v}$ and $\beta \mathrm{v}$ showed similar behaviour, in which both parameters decreased as a function of temperature of treatment. This reduction was significant only at $200^{\circ} \mathrm{C}$.

Thermally modified wood largely increases its dimensional stability and reduced its hygroscopicity due to the degradation of hemicelluloses, polymer reticulation and breaking of hydroxyl groups from amorphous zone of cellulose (Weiland and Guyonnet 2003, Rousset et al. 2004, Wikberg and Maunu 2004).

On the other hand, WA did not present significant changes after thermal treatments. Nevertheless, a tendency of reduction as a function of treatment temperature was observed. The behaviour of WRE confirmed a significant reduction of hygroscopicity of wood at $200^{\circ} \mathrm{C}$.

Differently from properties of dimensional stability, significant changes in the mechanical properties (Table 3) of thermally modified wood are negative.

Table 3. Mean values of modulus of elasticity (MOE) and modulus of rupture (MOR) of Luehea divaricata (açoita-cavalo) untreated and thermally treated wood.

\begin{tabular}{ccc}
\hline Treatment $\left({ }^{\circ} \mathrm{C}\right)$ & $\mathrm{MOE}(\mathrm{MPa})$ & $\mathrm{MOR}(\mathrm{MPa})$ \\
\hline Control $(20)$ & $8462,29 \mathrm{a}(1766,00)$ & $81,77 \mathrm{a}(10,39)$ \\
160 & $9022,82 \mathrm{a}(1508,27)$ & $87,50 \mathrm{a}(6,67)$ \\
180 & $8443,37 \mathrm{a}(1077,65)$ & $83,79 \mathrm{a}(9,05)$ \\
200 & $8940,47 \mathrm{a}(1079,42)$ & $63,04 \mathrm{~b}(13,01)$ \\
\multirow{2}{*}{ ANOVA } & $\mathrm{F}=0,64$ & $\mathrm{~F}=14,39 * *$ \\
& $\mathrm{p}=0,5956$ & $\mathrm{p}>0,0001$ \\
\hline
\end{tabular}

Statistical prerequisites as in Table 1 .

Açoita-cavalo wood was susceptible to a significant reduction of MOR at $200^{\circ} \mathrm{C}$. MOR decreased $\sim 23 \%$. Likewise, a significant and negative correlation between temperature of treatment and MOR $(r=-0,70)$ was observed.

Moura et al. 2012 reported that MOR of rose gum thermally modified wood presented a negative and significant correlation $(\mathrm{r}=-0,56)$ with the temperature of treatment, while MOR of Caribbean pinewood was not affected. The authors stated that MOR of rose gum wood was affected after thermal treatments at $180^{\circ} \mathrm{C}$.

Winandy and Lebow (2001) obtained a coefficient of determination of 0,75 for estimating mechanical strength loss of thermally modified wood. Strength loss occurred due to the degradation of carbohydrates during thermal treatments. Treatments between 200 and $260^{\circ} \mathrm{C}$ can cause significant degradation in hemicelluloses content of wood, which release a great content of acetic acid (Weiland et al. 1998). 
MOE did not present a statistical variation as a function of temperature of treatment. Nevertheless, stiffness of açoita-cavalo thermally modified wood showed a tendency to increase with increasing temperature of treatment. Mean values of control and thermally treated samples hold between 8000 and $9000 \mathrm{MPa}$.

Similar results were found by Calonego et al. (2012), who did not observe a significant variation of MOE of rose gum thermally modified wood after tests of static bending and compression parallel to fibres. Bhuiyan et al. (2000) reported that non-modification of MOE is related to the increase of cellulose crystallisation and thickness of crystallites.

The thermal treatments significantly changed the brittleness of acoita-cavalo wood (Table 4). However, only exposure at $200^{\circ} \mathrm{C}$ was able to change significantly the brittleness, i.e, thermal treatments at 140 and $160^{\circ} \mathrm{C}$ did not significantly modify this property when compared to the control treatment.

Table 4. Brittleness changes of Luehea divaricata (açoita-cavalo) untreated and thermally treated wood.

\begin{tabular}{ccc}
\hline Treatment $\left({ }^{\circ} \mathrm{C}\right)$ & Brittleness $(\%)$ & $\mathrm{CV}(\%)$ \\
\hline Control $(20)$ & $16,87 \mathrm{a}$ & 6,65 \\
160 & $22,21 \mathrm{a}$ & 30,33 \\
180 & $23,67 \mathrm{a}$ & 19,11 \\
200 & $59,49 \mathrm{~b}$ & 20,51 \\
\hline \multirow{2}{*}{ ANOVA } & $\mathrm{F}=72,46^{* *}$ \\
\end{tabular}

Statistical prerequisites as in Table 1 .

The highest decrease of brittleness was $71,64 \%$ for the treatment at $200^{\circ} \mathrm{C}$. This behaviour was expected because high temperatures tend to significantly reduce the mechanical strength of wood. Moreover, a Pearson correlation presented a high correlation of brittleness with $\operatorname{WL}(0,86)$, MOR $(-0,87)$ and $L^{*}(-0,86$ in radial and $-0,81$ in tangential). Phuong et al. (2007) observed a similar behaviour in Styrax tonkinensis thermally modified wood at $160-200^{\circ} \mathrm{C}$.

Thermal treatments present wide utilisation due to the possibility of colour modifications of wood, mainly for aesthetic uses. Visual analysis confirms absence of perceptible darkening (unaided eye) between control treatment and treatment at 160 and $180^{\circ} \mathrm{C}$. A significant darkening (unaided eye) in both radial and tangential sections is observed only at $200^{\circ} \mathrm{C}$ (Table 5). 
Table 5. Colour changes in Luehea divaricata (açoita-cavalo) untreated and thermally treated wood.

\begin{tabular}{|c|c|c|c|c|c|c|c|}
\hline & $\mathrm{T}\left({ }^{\circ} \mathrm{C}\right)$ & $L^{*}$ & $a^{*}$ & $b^{*}$ & $C^{*}$ & $h\left(^{\circ}\right)$ & $\Delta E$ \\
\hline \multirow{4}{*}{ 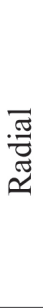 } & Control & $\begin{array}{c}54,80 \mathrm{a} \\
(6,95)\end{array}$ & $\begin{array}{l}4,40 \mathrm{ab} \\
(17,26)\end{array}$ & $\begin{array}{c}17,98 \mathrm{a} \\
(9,73)\end{array}$ & $\begin{array}{c}18,52 \mathrm{a} \\
(9,81)\end{array}$ & $\begin{array}{c}76,25 \mathrm{a} \\
(2,32)\end{array}$ & - \\
\hline & 160 & $\begin{array}{c}54,27 \mathrm{a} \\
(9,20)\end{array}$ & $\begin{array}{c}4,78 \mathrm{a} \\
(14,50)\end{array}$ & $\begin{array}{c}18,96 \mathrm{a} \\
(9,56)\end{array}$ & $\begin{array}{c}19,95 \mathrm{a} \\
(9,76)\end{array}$ & $\begin{array}{c}75,77 \mathrm{a} \\
(2,39)\end{array}$ & 1,18 \\
\hline & 180 & $\begin{array}{c}53,01 \mathrm{a} \\
(5,22)\end{array}$ & $\begin{array}{c}4,21 \mathrm{~b} \\
(11,37)\end{array}$ & $\begin{array}{c}18,73 \mathrm{a} \\
(3,52)\end{array}$ & $\begin{array}{c}19,41 \mathrm{a} \\
(7,35)\end{array}$ & $\begin{array}{c}76,93 \mathrm{a} \\
(1,49)\end{array}$ & 1,95 \\
\hline & 200 & $\begin{array}{l}41,06 \mathrm{~b} \\
(13,69)\end{array}$ & $\begin{array}{l}6,60 \mathrm{c} \\
(8,07)\end{array}$ & $\begin{array}{l}17,63 \mathrm{a} \\
(17,44)\end{array}$ & $\begin{array}{l}18,97 \mathrm{a} \\
(15,45)\end{array}$ & $\begin{array}{c}68,23 \mathrm{~b} \\
(5,95)\end{array}$ & 13,92 \\
\hline \multirow{2}{*}{\multicolumn{2}{|c|}{ ANOVA }} & $\mathrm{F}=52,31 * *$ & $\mathrm{~F}=63,57 * *$ & $\mathrm{~F}=1,87$ & $\mathrm{~F}=1,88$ & $\mathrm{~F}=59,89 * *$ & - \\
\hline & & $\mathrm{p}<0,0001$ & $\mathrm{p}<0,0001$ & $\mathrm{p}=0,14$ & $\mathrm{p}=0,1396$ & $\mathrm{p}<0,0001$ & - \\
\hline \multirow{4}{*}{ 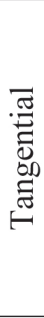 } & Control & $\begin{array}{c}51,93 \text { a } \\
(9,79)\end{array}$ & $\begin{array}{c}5,15 \mathrm{a} \\
(34,06)\end{array}$ & $\begin{array}{l}18,89 \mathrm{a} \\
(15,17)\end{array}$ & $\begin{array}{l}19,74 \mathrm{a} \\
(17,04)\end{array}$ & $\begin{array}{c}74,09 a \\
(5,06)\end{array}$ & - \\
\hline & 160 & $\begin{array}{c}53,74 \mathrm{a} \\
(7,53)\end{array}$ & $\begin{array}{c}4,96 \mathrm{a} \\
(18,71)\end{array}$ & $\begin{array}{c}19,23 \mathrm{a} \\
(7,20)\end{array}$ & $\begin{array}{c}19,89 a \\
(7,66)\end{array}$ & $\begin{array}{c}75,50 \mathrm{a} \\
(2,39)\end{array}$ & 1,85 \\
\hline & 180 & $\begin{array}{c}50,48 \mathrm{a} \\
(8,43)\end{array}$ & $\begin{array}{c}4,60 \mathrm{a} \\
(19,23)\end{array}$ & $\begin{array}{c}18,70 \mathrm{a} \\
(3,24)\end{array}$ & $\begin{array}{c}19,70 \mathrm{a} \\
(5,86)\end{array}$ & $\begin{array}{c}76,03 \mathrm{a} \\
(2,72)\end{array}$ & 1,56 \\
\hline & 200 & $\begin{array}{l}39,57 \mathrm{~b} \\
(15,90)\end{array}$ & $\begin{array}{l}6,70 \mathrm{~b} \\
(3,88)\end{array}$ & $\begin{array}{l}17,30 \mathrm{a} \\
(19,33)\end{array}$ & $\begin{array}{l}18,71 \mathrm{a} \\
(17,00)\end{array}$ & $\begin{array}{c}67,38 \mathrm{~b} \\
(5,06)\end{array}$ & 12,56 \\
\hline \multicolumn{2}{|c|}{ ANOVA } & $\begin{array}{c}\mathrm{F}=39,01 * * \\
\mathrm{p}<0,0001\end{array}$ & $\begin{array}{c}\mathrm{F}=11,70 * * \\
\mathrm{p}<0,0001\end{array}$ & $\begin{array}{l}F=2,73 \\
p=0,05\end{array}$ & $\begin{array}{l}\mathrm{F}=0,97 \\
\mathrm{p}=0,41\end{array}$ & $\begin{array}{c}\mathrm{F}=35,13 * * \\
\mathrm{p}<0,0001\end{array}$ & - \\
\hline
\end{tabular}

Statistical prerequisites as in Table 1.

The parameter $L^{*}$ was inversely proportional to the temperature of treatment in both anatomical sections. However, $L^{*}$ significantly decreased only for treatment at $200^{\circ} \mathrm{C}$, which was $\sim 25 \%$ in radial section and $\sim 24 \%$ in tangential section. According to Bekhta and Niemz (2003), thermal treatments cause darkening of wood mainly in the first 4 hours of treatment and increase at $200^{\circ} \mathrm{C}$ or higher.

A slight increase of $a^{*}$ as a function of the temperature of treatment in both anatomical sections was observed. On the other hand, $b^{*}$ values remained between 17 and 19 and not showed a tendency as a function of temperature of treatment.

Naturally, açoita-cavalo wood presents $C^{*}$ referred to grey tones (relationship $L^{*} \mathrm{x} C^{*}$ ). Despite thermal modification of wood, parameters $b^{*}$ and $C^{*}$ were constant as a function of temperature of treatment, i.e., thermally modified wood did not increase their grey tones (decrease of $C^{*}$ ) or vivacity (increase of $C^{*}$ ).

The parameter $h$ showed slight changes only at $200^{\circ} \mathrm{C}$, representing small loss of yellow colour $(10 \%$ in radial section and $8 \%$ in tangential section) and increase of red colour.

The parameter $\Delta E$ was inversely proportional to the temperature of treatment and confirmed occurrence of changes on colour of açoita-cavalo thermally modified wood. Values of $\Delta E$ higher than 2-3 indicate that the human eye is able to distinguish the colour of materials (Hon and Minemura 1991, Sundqvist 2002).

All parameters of surface roughness of treated samples decreased significantly when compared to untreated samples (Table 6). The highest reduction of Ra was $25,62 \%$ for treatment at $200^{\circ} \mathrm{C}$. However, mean values of surface roughness of wood thermally treated at $160-200^{\circ} \mathrm{C}$ did not show statistical difference, in which treatment at $160^{\circ} \mathrm{C}$ was sufficient to modify significantly the surface roughness of açoita-cavalo wood. 
Table 6. Surface roughness changes in radial direction of Luehea divaricata (açoita-cavalo) untreated and thermally treated wood.

\begin{tabular}{ccccc}
\hline Treatment $\left({ }^{\circ} \mathrm{C}\right)$ & $\mathrm{Ra}(\mu \mathrm{m})$ & $\mathrm{Rz}(\mu \mathrm{m})$ & $\mathrm{Rq}(\mu \mathrm{m})$ & $\mathrm{Rt}(\mu \mathrm{m})$ \\
\hline Control $(20)$ & $10,77 \mathrm{a}(15,94)$ & $30,47 \mathrm{a}(15,97)$ & $11,61 \mathrm{a}(15,69)$ & $30,77 \mathrm{a}(15,97)$ \\
160 & $8,43 \mathrm{~b}(24,66)$ & $23,82 \mathrm{~b}(24,68)$ & $8,98 \mathrm{~b}(24,80)$ & $24,05 \mathrm{~b}(24,68)$ \\
180 & $8,98 \mathrm{~b}(25,67)$ & $25,41 \mathrm{~b}(25,68)$ & $9,51 \mathrm{~b}(25,11)$ & $25,36 \mathrm{~b}(26,47)$ \\
200 & $8,01 \mathrm{~b}(11,84)$ & $22,16 \mathrm{~b}(14,24)$ & $8,21 \mathrm{~b}(14,66)$ & $22,38 \mathrm{~b}(14,23)$ \\
\hline \multirow{2}{*}{ ANOVA } & $\mathrm{F}=7,00^{* *}$ & $\mathrm{~F}=7,63^{* *}$ & $\mathrm{~F}=9,02^{* *}$ & $\mathrm{~F}=7,66^{* *}$ \\
& $\mathrm{p}=0,004$ & $\mathrm{p}=0,0002$ & $\mathrm{p}=0,0001$ & $\mathrm{p}=0,0002$ \\
\hline
\end{tabular}

Mean values in the same column followed by the same letter are not statistically different at level of $5 \%$ by the Tukey Test; $\mathrm{p}=$ probability; $\mathrm{F}=$ calculated value of $\mathrm{F}$; ${ }^{* *}$ Significant at $5 \%$ of probability of error; Value between parenthesis corresponding to coefficient of variation (\%).

These results presented similar behaviour of other studies (Gündüz et al. 2008, Korkut and Guller 2008) and confirmed the increase of quality of wood surface. According to Gündüz et al. (2008), decrease of roughness is important for many applications of solid wood because can reduce the losses in planning machine and can increase the quality of wood surface.

\section{CONCLUSIONS}

This study investigated the changes on physical and mechanical properties of Luehea divaricata (açoitacavalo) wood thermally modified at $160-200^{\circ} \mathrm{C}$ for 2 hours. In general, physical and mechanical properties of açoita-cavalo thermally modified wood showed significant modifications at $200^{\circ} \mathrm{C}$. Dimensional stability increased and equilibrium moisture content decreased as a function of temperature. Mechanical strength of thermally modified wood significantly decreased and, consequently, brittleness increased at $200^{\circ} \mathrm{C}$. Wood colour was influenced by the reduction of lightness $\left(L^{*}\right)$ and decrease of surface roughness was observed, which enable new practical uses of açoita-cavalo wood when aesthetic factors are considered.

\section{ACKNOWLEDGMENTS}

The authors wish to thank CNPq (National Counsel of Technological and Scientific Development) and CAPES (Coordination for the Improvement of Higher Level Personnel) for the financial support. 


\section{REFERENCES}

Akyildiz, M.H.; Ates, S.; Ozdemir, H. 2009. Technological and chemical properties of heattreated Anatolian black pine wood. Journal of Biotechnology 8 (11): 2565-2572.

ASTM International. ASTM. 2000. Standards methods of testing small clear specimens of timber. ASTM. D143-94. West Conshohocken.

Bal, B.C. 2013. Effect of heat treatment on the physical properties of heartwood and sapwood of Cedrus libani. Bioresources 8 (1): 211-219.

Bekhta, P.; Niemz, P. 2003. Effect of High Temperature on the Change in Color, Dimensional Stability and Mechanical Properties of Spruce Wood. Holzforschung 57 (5): 539-546.

Bhuiyan, M.T.R.; Hirai, N.; Sobue, N. 2000. Changes of crystallinity in wood cellulose by heat treatment under dried and moist conditions. Journal of Wood Science 46 6): 431-436.

Calonego, F.; Severo, E.; Ballarin, A. 2012. Physical and mechanical properties of thermally modified wood from E. grandis. European Journal of Wood and Wood Products 70 (4): 453-460.

Esteves, B.; Velez- Marques, A.; Domingos, I.; Pereira, H. 2008. Heat-induced colour changes of pine (Pinus pinaster) and eucalypt (Eucalyptus globulus) wood. Wood Science and Technology 42 (5): 369-384.

Gündüz, G.; Aydemir, D. 2009. Some Physical Properties of Heat-Treated Hornbeam (Carpinus betulus L.) Wood. Drying Technology 27 (5): 714-720.

Gündüz, G.; Korkut, S.; Korkut, D.S. 2008. The effects of heat treatment on physical and technological properties and surface roughness of Camiyanı Black Pine (Pinus nigra Arn. subsp. pallasiana var. pallasiana) wood. Bioresource Technology 99 (7): 2275-2280.

Hill, C.A.S. 2006. Wood Modification: Chemical, Thermal and Other Processes. 1st ed. John Wiley \& Sons, Chichester.

Hon, D.N.S.; Minemura, N. 1991. Color and Discoloration. In: Wood and Cellulosic Chemistry. Hon DN-S,Shiraishi N, Eds. Marcel Dekker, New York.

Korkut, D.S.; Guller, B. 2008. The effects of heat treatment on physical properties and surface roughness of red-bud maple (Acer trautvetteri Medw.) wood. Bioresource Technology 99 (8): 2846-2851.

Militz, H.; Tjeerdsma, B. 2001. Heat treatment of wood by the Plato-Process. Proceedings of Special Seminar of Coast Action E22, Antibes, France.

Moura, L.F.; Brito, J.O.; Júnior, G.B. 2012. Efeitos da termorretificação na perda de massa e propriedades mecânicas de Eucalyptus grandis e Pinus caribaea VAR. hondurensis. Floresta 42 (2): 305-314.

Phuong, L.; Shida, S.; Saito, Y. 2007. Effects of heat treatment on brittleness of Styrax tonkinensis wood. Journal of Wood Science 53 (3): 181-186.

Pincelli, A.L.P.S.M.; Moura, L.F.; Brito, J.O. 2012. Effect of thermal rectification on colors of Eucalyptus Saligna and Pinus caribaea woods. Maderas. Ciencia y tecnología. 14 (2): 239-248. 
Rizzini, C.T. 1995. Árvores e madeiras úteis do Brasil: manual de dendrologia brasileira. Edgar Blucher, São Paulo. 294 p.

Rousset, P.; Perré, P.; Girard, P. 2004. Modification of mass transfer properties in poplar wood (P. robusta) by a thermal treatment at high temperature. European Journal of Wood and Wood Products 62 (2): 113-119.

Sundqvist, B. 2002. Color response of Scots pine (Pinus sylvestris), Norway spruce (Picea abies) and birch (Betula pubescens) subjected to heat treatment in capillary phase. European Journal of Wood and Wood Products 60 (2): 106-114.

Sundqvist, B.; Karlsson, O.; Westermark, U. 2006. Determination of formic-acid and acetic acid concentrations formed during hydrothermal treatment of birch wood and its relation to colour, strength and hardness. Wood Science and Technology 40 (7): 549-561.

Weiland, J.; Guyonnet, R.; Gibert, R. 1998. Analyse de la pyrolyse menagee du bois par un couplage TG-DSC-IRTF. Journal of Thermal Analysis and Calorimetry 51 (1): 265-274.

Weiland, J.J.; Guyonnet, R. 2003. Study of chemical modifications and fungi degradation of thermally modified wood using DRIFT spectroscopy. European Journal of Wood and Wood Products 61 (3): 216-220.

Wikberg, H.; Maunu, S.L. 2004. Characterisation of thermally modified hard- and softwoods by $13 \mathrm{C}$ CPMAS NMR. Carbohydrate Polymers 58 (4): 461-466.

Winandy, J.E.; Lebow, P.K. 2001. Modeling strength loss in wood by chemical composition. PartI. An individual component model for southern pine. Wood and Fiber Science 33 (2): 239-254. 